\title{
ALL THAT REMAINS
}

\author{
A holiday to remember.
}

\section{BY SHANE D. RHINEWALD}

$\mathrm{O}$ nly the foundation of the house still existed, a bunch of cinder blocks strangled by weeds. The willow in the backyard had been reduced to a stump, and just one arm of the swing set still poked up from the ground - a gnarled, rusted thing.

"That's where I grew up," David said. He sprayed cleaning fluid on the rental hovercraft's windscreen to give the kids a better look.

"Doesn't look like much," Jackson said. With a shrug, he pulled the virtual-reality glasses back over his eyes. "Let me know when we're off this planet."

"Dad, this is the worst holiday ever," Clara added. She clicked her bubblegum.

David sighed. "I just have a few more things to show you."

Clara rolled her eyes; they were molasses like her mother's had been. "This place is dark, charred and smelly. Can we go now?"

"I met your mother there," David said. He nodded towards the empty, ash-filled car park below. "She was crossing campus in quite the hurry, and I nearly hit her with my car."

Clara shifted in her seat. "I can't believe people here still had cars, even back then. Heck, I don't think anyone on Centana has ever owned a car, and it's been a colony for 200 years."

David pictured driving down the highway along the Atlantic with Brianna, the car's top down, the salty spray in their faces. "I guess people who remained on Earth after the space exodus still preferred simpler things."

"Well I don't," Clara said. "When I get my licence next month, can I have a four-seater hovercraft?"

Jackson flipped his glasses up long enough to say: "What about me? I want one, too."

"I get the first one. I'm the eldest."

"By two minutes!" Jackson said.

David hardly heard his children's argument. Instead, he stared at the crater in the centre of the car park. He had been gone for only two years before the war turned Earth into an uninhabitable husk and his parents into dust. From all those light years away on Centana, he could do nothing to help.

David blinked. "Do you want to see where you were born?"
"Don't remind me," Clara said. She leaned back in her seat. "I tell my friends we were born on Colony 4 before we moved to Centana. That's less embarrassing." his. They had shared their first kiss kneedeep in the river's murky waters.

"You're going to have to put on your suits," David said.

Clara folded her arms. "You didn't say we would have to get out."

"It's better than sitting crammed in here any longer," Jackson said. He pulled up his seat to retrieve the gear; Clara scoffed a bit longer before she followed suit.

Once outside, David's breath felt sticky inside the helmet, and condensation coated the faceshield. Sweat dampened his armpits, and his breathing increased in tempo.

"Follow me," David said. He recognized a sharp turn in the riverbed, almost a right angle. The silvery fish used to jump here, and long ago David went on one knee in the grass just beside this spot. $\mathrm{He}$ remembered the way Brianna had
“This used to be a hospital," David said. Not much existed below, though — just some sad, sagging rebar choked with vines. "We were all there. Even your uncle took a ship in from Servius to see your birth."

Clara shrugged. "I don't remember it."

"You're not supposed to. You were a baby," Jackson said with a snort.

"I don't remember Earth at all for that matter. And I'm glad I don't. What kind of backwards people fry each other and their planet, too?"

"Your ancestors," David said.

"I lived here six months, Dad," Clara said. "I'm a Centanan, and we're a bit more sophisticated than that."

"I should have brought you back here sooner," David said, more to himself than to them. It had been his fault that they looked down their nose at the Earthlings like so many others did. He had never had the courage to talk much about his homeland - or why he had fled it. It had been nothing to do with the impending war.

"I just have one more thing to show you. Then we can catch the first ship out of here."

David put the hovercraft down in a dried riverbed. The place used to team with lilies and milkweeds, but now only leathery $\rightarrow$ NATURE.COM

Follow Futures: @ @NatureFutures $f$ go.nature.com/mtoodm shrubs grew from the hard-packed dirt. He pictured walking along the bank, Brianna's warm hand in cried when he produced the platinum band.

"Where?" Clara asked after a bit of walking.

"Here," David said. He stopped over a granite marker pressed into the dirt, a single name and date etched on its dull surface. On Centana, they would probably have given her something the size of a monument, but here, Brianna needed only this.

"What is it?" Clara asked.

"This is where we buried your mother," David said. A pause followed. "You were both here when we put her in the ground, but you were just a couple months old."

"You don't talk about her much," Clara said softly, her voice muffled by her helmet. "You should talk about her more, you know."

David sank to his knees and traced Brianna's name in the stone with a forefinger. Talking about her just made him remember the accident and all the things that he had tried so hard to forget while on Centana.

Jackson put a hand on his shoulder. "Dad?"

The tears collected inside David's helmet. "Yes?"

"Sorry. You know, about complaining so much."

David nodded. "Do you want to go now?"

"No. Let's stay," Clara said. "Just a while longer." -

Shane D. Rhinewald is a communications professional by day and writes speculative fiction by night (except when there's hockey on $T V$, of course). 